\title{
Evaluation of the Implementation of the Discovery Learning Model by Utilizing M-Edukasi
}

\author{
Manikowati 1 \\ manikowati@kemdikbud.go.id
}

Abstract: Implementing the best learning during the COVID-19 pandemic is challenging. Also, applying a learning model integrated with ICT is urgently required. It leads to applying discovery learning using mobile learning, hereinafter referred to as M-Edukasi. This research aimed to evaluate the strengths and the weaknesses of the model using $M$ Edukasi to provide recommendations for the stakeholders, in this case, teachers, school principals, and the Center for Multimedia Education and Culture Development (BPMPK), for further improvements. To obtain the data, the applied research methodology was descriptive qualitative. The instruments used were document notes, observation sheets, and interview guidance. The results showed that three learning processes, namely planning, implementing, and assessing, were interconnected and influential. Better processes in the preceding step would make the later ones better and vice versa. Meanwhile, the weaknesses were apparently influenced by vague and unspecific statements in the lesson plan (RPP). Moreover, there was the less optimal use of MEdukasi. There was no usage manual completed the medium. Those weaknesses, then, affected the students' learning outcomes that were less than optimal.

Keywords: $\quad$ Evaluation, Implementation, Discovery Learning, M-Edukasi

Abstrak: $\quad$ Menerapkan pembelajaran yang terbaik di masa pandemic Covid 19 sangat menantang. Mengimplementasikan model pembelajaran dengan mengintegrasikan TIK sangat dibutuhkan, termasuk mengimplementasikan Discovery Learning dengan menggunakan mobile learning, yang selanjutnya disebut m-Edukasi.Penelitian ini bertujuan untuk mengevaluasi kelebihan dan kelemahan model tersebut menggunakan m-Edukasi sehingga memberikan rekomendasi kepada pihak yang berkepentingan, dalam hal ini, guru dan kepala sekolah serta BPMPK untuk melakukan perbaikan. Untuk mendapatkan data, metodologi yang digunakan adalah kualitatif deskriptif. Instrumen yang digunakan adalah catatan dokumen, lembar observasi, dan panduan wawancara. Data yang diperoleh menunjukkan bahwa ketiga proses pembelajaran- perencanaan, pelaksanaan, dan penilaian saling berhubungan dan mempengaruhi. Proses yang baik pada langkah sebelumnya berdampak baik pada langkah sesudahnya dan sebaliknya. Kelemahan yang diperoleh sesungguhnya berawal dari pernyataan yang tidak detil dan kurang jelas di Rencana Pelaksanaan Pembelajaran (RPP). Selain itu, ditemukan bahwa penggunaan mobile Edukasi kurang optimal. Tidak terdapat petunjuk pemanfaatan yang melengkapinya. Hal tersebut kemudian berdampak pada pemerolehan hasil belajar yang kurang optimal.

Kata Kunci: $\quad$ Evaluasi, Implementasi, Discovery Learning, m-Edukasi

Submitted: December $2020 \quad$ Reviewed: January $2021 \quad$ Accepted: March $2021 \quad$ Published: March 2021

${ }^{1}$ Balai Pengembangan Multimedia Pendidikan dan Kebudayaan (BPMPK), Kementerian Pendidikan dan Kebudayaan Repulbik Indonesia 
E dukasi at URL http://m-edukasi.kemdikbud.go.id is a website developed by the Center for Multimedia Education and Culture Development (BPMPK) Ministry of Education and Culture, Indonesia. This website contains content in the form of learning media that the education community can use to improve the learning's quality being held. Through M-Edukasi, BPMPK strives to provide content services for higher quality learning. During its development, M-Edukasi content has developed a wide variety of learning media, whether it is run via PC/computer or laptop or mobile devices such as tablets or smartphones. Besides, there are also learning media developed offline and online. Several variations of learning media that can be utilized by using a PC or laptop are media catalogs, E-Culture, stock media, Interactive Learning Multimedia (MPI), and teaching aids (or better known as m-Kit Guru [m-Kit for teachers]). Meanwhile, media variations that are run using mobile devices include mobile V-Lab, mobile Vocations, Augmented Reality, e-Comics, and Mobile Education. It is hoped that the learning contents in the form of various learning media can be used to optimize the applied learning, especially during the COVID-19 pandemic.

On the other hand, the COVID-19 pandemic has had a tremendous impact on every aspect of human life, including education in Indonesia. All learning societies in this country are trying to find an appropriate format to implement their learning. Each school seeks to find a learning model that can be applied with appropriate technology to facilitate teaching and learning activities during the pandemic, both as a learning process tool and learning media. With a pandemic like this, technology integration, including learning media, is indispensable for learning. However, no matter how sophisticated the media or technology is used, if the learning model applied is not suitable, then the results are less than optimal. Conversely, even though the learning media used is simple, if used in the right learning model, the learning media is like an atomic bomb, which can change learning outcomes to be optimal (Manikowati, 2017). In other words, learning media will have a tremendous effect if used appropriately in the applied learning model.

Afandi, Chalamah, and Wardani (2013) define learning models as systematic procedures or patterns used as guidelines for achieving learning objectives, in which there are strategies, techniques, methods, materials, media, and learning assessment tools. Nurdyansyah and Fahyuni (2016) explain a learning model as a plan or pattern used to form a curriculum (long-term learning plans), design learning materials, and guide learning in other classes. Of these two definitions, the learning model, in other words, is a pattern or procedure planned to achieve learning objectives, in which there are strategies, methods, techniques, materials, and media used to guide learning in the classroom accompanied by appropriate assessment tools. One of the learning models that can be applied is discovery learning.

According to Brown (2006), discovery learning is a learning model that invites students to actively participate in the learning process rather than merely giving instructions directly into the brain tissue. The purpose of implementing this learning model is to enable students to have new knowledge from direct learning experiences. The problems engineered by the teacher are based on the problems faced and are the students' needs. Students are allowed to experience firsthand learning to gain new knowledge of the problems at hand. By going through the experience directly, it is hoped that students will better absorb the knowledge they pass through. As seen in Edgar Dale's cone of experience in Nikmah (2017) below: 


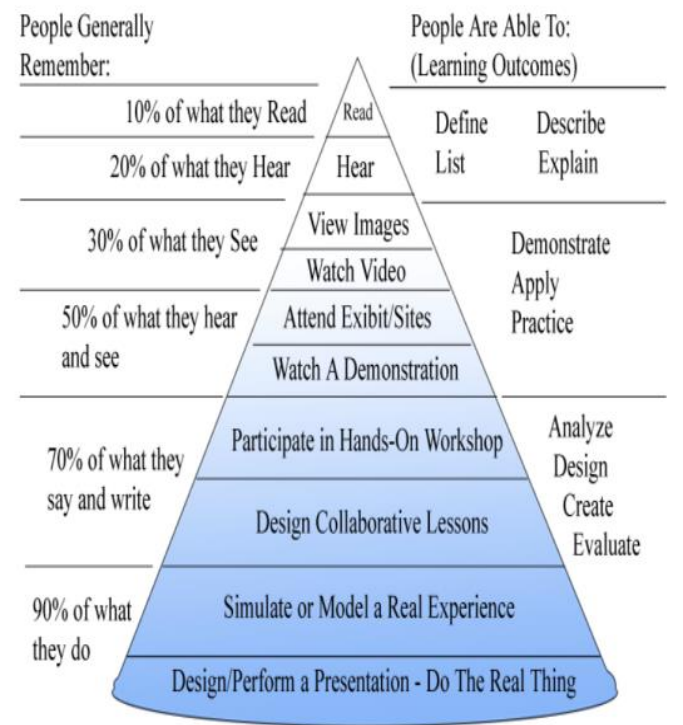

Figure 1. Edgar Dale's Cone of Experience

From Edgar Dale's cone figure, it can be seen that by experiencing it directly or at least from the simulation, students are predicted to receive $90 \%$ of their learning outcomes. Besides, discovery learning models are predicted to lead students to receive optimal learning outcomes.

Furthermore, Brown (2006) stated that discovery learning and the use of technology in learning today are interrelated and integrated. If students find it challenging to explore media in the learning process directly, they can use alternative learning media. One of the alternative media that can be used in learning is the Mobile Education found in M-Edukasi.

M-Edukasi is a variant of offline learning media developed by BPMPK and presented in a tutorial format using a mobile device. By using the tutorial presentation format, this type of media has quite complete material content. Additionally, it is also equipped with tests or exercises. With such conditions, students can use this learning media independently without being too dependent on the teacher. On the other hand, teachers need to plan carefully what students will go through to gain meaningful learning experiences. Of course, this preparation requires the carrying capacity of school policy stakeholders in its application or implementation.

Implementation is a real action taken by a person or group of people on a well-designed plan and marked by policies that support it. Nurdin Usman (2002) stated that implementation leads to activities and actions, or activities carried out systematically and bound by mechanisms. Furthermore, Tachjan (2006) defines implementation as an action or activity carried out after a policy's existence. From this definition, the implementation's characteristics are 1) there is real and systematic action, 2) there is a mechanism designed before action, and 3) there is a supporting policy; likewise, the implementation of discovery learning integrated with digital technology.

Implementing the discovery learning model by utilizing M-Edukasi needs to be evaluated to know its advantages and disadvantages to decide what improvements need to be made afterward. Arifin (2013) argues that, in essence, evaluation is a systematic and continuous process to determine the quality (value and meaning) of something based on specific considerations and criteria to make a decision. Novita, Irawati, and Jumiarni (2018) recommend that a six-level cognitive study be carried out after evaluating the model implementation against student activity and learning outcomes. Besides, Rahmayani (2019) decided to use the discovery learning model because it affected student 
achievement when using video media. Riyaningsih, Maryono, and Harini (2017) employed discovery learning because this model could shape students' characters in art learning. Moreover, Purwaningsih also researched the implementation of the discovery learning model compared to Problem-Based Learning. The two models studied showed that students had excellent mathematical abilities.

The four research has evaluated the effect of the discovery learning model implementation on the achievement of student competencies, one of which is using video media. The research did not highlight the process by which the teacher applied it. Through this study, the researcher hopes to provide recommendations on improving the discovery learning model implementation using M-Edukasi by the teacher as the implementer, the principal as the supervisor, and BPMPK as the developer of MEdukasi after paying attention to its strengths and weaknesses

\section{RESEARCH METHODS}

This study evaluated the discovery learning model implementation by utilizing mobile education on the M-Edukasi website. This research is descriptive qualitative in nature. The data and information obtained were data and information in the form of narratives of the learning process and outcomes, which were analyzed inductively and presented descriptively to reveal the meaning of the learning conditions, including the strengths and weaknesses of ongoing learning. Bogdan and Taylor (1982) in Moleong (2008) state that qualitative research is a research procedure that produces descriptive data in the form of written or spoken words from the people or observed behavior. Furthermore, it is conveyed that descriptive qualitative research has the characteristics of 1) the researcher himself acts as an instrument to directly visit the data source, 2) the data collected in the research tends to be in the form of words rather than numbers, 3) the study results emphasize the process, not solely on the results, 4) research through induction analysis, where the researcher reveals the meaning of the conditions that occur, and 5) the researcher expresses meaning as essential with a qualitative approach.

This evaluation research was designed in a naturalistic qualitative manner (Moleong, 2008). It indicated that the evaluation was carried out in accordance with the conditions in the field to obtain results and studies described in depth. Besides, this study is a diagnostic evaluation (Arifin, 2013), which aimed to diagnose or examine the learning process so that the advantages and disadvantages of applying the learning model carried out by utilizing M-Edukasi can be used as consideration for improving the implementation of the next model. Meanwhile, this research's scope was limited to the discovery learning model implementation in Mathematics, with the topic of the chance of an incident using M-Edukasi entitled Evaluation of the Implementation of the Discovery Learning Model by Utilizing M-Edukasi

In this study, the evaluation process referred to the evaluation process presented by Asrul, Ananda, and Rosnita (2014), starting from the input, transformation, output, and feedback. This research process is shown in the figure 2 .

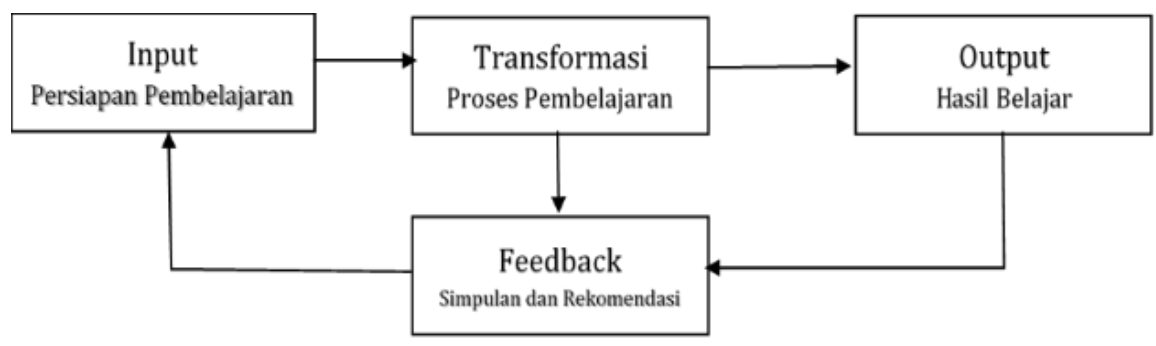

Figure 2. Evaluation Process of the Discovery Learning Model Implementation with M-Edukasi 
In this study, input was the preparation of learning carried out before implementing the discovery learning model using M-Edukasi. Input in this evaluation process was carried out by analyzing the lesson plan (RPP) document and learning outcomes. The transformation was the process of evaluating learning activities carried out by students and teachers by implementing the discovery learning model using M-Edukasi. Output was a process of evaluating the transformation process results, namely achieving the targeted competencies from the discovery learning model implementation by utilizing $\mathrm{M}$ Edukasi. Meanwhile, the feedback was the process of compiling conclusions and recommendations given to improve input based on the determined consideration components. In this case, it was the advantages and disadvantages of the applied aspects of learning.

Research on the discovery learning model implementation utilizing Mobile Education on the MEdukasi website was conducted on 20-30 November 2020 in a blended manner. Data mining in lesson plan documents and learning results and observations were done online, while in-depth interviews were conducted face-to-face. The main subject of this research was the teacher as the primary role in learning with students. The teacher studied was a teacher who taught Mathematics for the Social Studies major. This study's secondary subject was the principal, who acted as a manager and supervisor for the learning. Data and information collection techniques used in this learning model implementation were document analysis, indirect observation, and in-depth interviews. The three techniques were interrelated in making conclusions on the research results.

The document analysis technique was used to filter out the lesson plans' strengths and weaknesses prepared by the teaching teacher before carrying out learning and student learning outcomes after the implementation. Meanwhile, the indirect observation was employed because it was impossible to carry out direct learning observations. Besides, the learning carried out was full online learning utilizing Microsoft Teams - Office 365 so that learning took place in a virtual space. For this reason, the learning implementation was recorded, and the results were formatted in the form of a video to analyze the learning implementation's advantages and disadvantages applying the discovery learning model using mobile learning in M-Edukasi. Meanwhile, in-depth interviews were used to confirm document analysis and observations made by the researcher. In-depth questions and answers were conducted with teachers and school principals to confirm the learning process carried out from preparation, implementation, and post-learning.

The research data was collected using instruments in the form of document notes, observation sheets, and interview guides. Document notes were used to store data and information findings in the lesson plans that the teacher compiled and student learning outcomes. The observation sheet was employed to record the learning process at each of the steps carried out and the use of the learning media. The interview guide was utilized as a guide for the researcher in confirming the data and information. The research data validity on research regarding the discovery learning model implementation by utilizing Mobile Education at M-Edukasi at SMA Negeri 1 Wonogiri can be seen in the following figure.

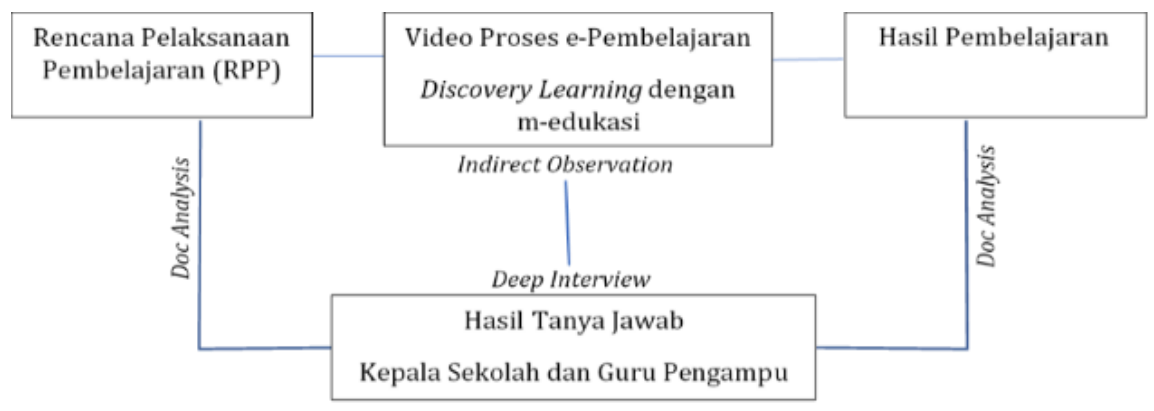

Figure 3. The research data validity 
This research used triangulation techniques and data sources. Triangulation of research techniques was carried out by document analysis, indirect observations, and in-depth interviews with school principals and teachers. Meanwhile, the triangulation of data sources came from the lesson plans document made by the teaching teacher and received by the principal, the video of the learning process carried out by the teaching teacher, student learning outcomes, and the interview results with school principals and teachers. Further, the data analysis process carried out in this study employed interactive analysis techniques (Milles and Hubberman, 1992). There were four processes in this evaluation data analysis: 1) data collection, 2) data reduction, 3) data presentation, and 4) drawing conclusions.

\section{RESULTS AND DISCUSSION}

After analyzing three documents from data sources regarding the discovery learning model implementation using M-Edukasi in the form of document notes, observation results, and in-depth interviews, the evaluation results of the input, transformation, output, and feedback processes were obtained as follows.

\section{Input Process}

Based on the data analysis results, the advantages and disadvantages were found on the input process of implementing the discovery learning model by utilizing Mobile Education on the M-Edukasi website in the following table.

\section{Table 1. Strengths and Weaknesses in the Input Process}

\begin{tabular}{|c|c|c|c|}
\hline No. & Strengths & No. & Weaknesses \\
\hline 1 & $\begin{array}{l}\text { The teaching teacher has already had } \\
\text { good preparation by compiling lesson } \\
\text { plans. }\end{array}$ & 1 & $\begin{array}{l}\text { Learning objectives have not been well } \\
\text { stated in the lesson plan and are not yet in } \\
\text { accordance with the applied discovery } \\
\text { learning model's spirit. }\end{array}$ \\
\hline 2 & $\begin{array}{l}\text { The lesson plan documents prepared } \\
\text { have met the lesson plans for } \\
\text { independent learning by integrating ICT, } \\
\text { especially M-Edukasi. }\end{array}$ & 2 & $\begin{array}{l}\text { The syntax included in the lesson plan } \\
\text { documents was still global and has not } \\
\text { been detailed, so that it was still difficult to } \\
\text { read the activities that would take place at } \\
\text { each step of the lesson. }\end{array}$ \\
\hline 3 & $\begin{array}{l}\text { The teacher could select and sort the } \\
\text { learning media needed to facilitate the } \\
\text { learning carried out. }\end{array}$ & 3 & $\begin{array}{l}\text { The planned learning activities seemed to } \\
\text { be still stuck with the opening, the core, } \\
\text { and the closing, so that there were } \\
\text { redundant learning steps at the beginning } \\
\text { and the core. }\end{array}$ \\
\hline 4 & $\begin{array}{l}\text { There have been attempts from teachers } \\
\text { to include learning resources and learning } \\
\text { media in the lesson plans. }\end{array}$ & 4 & $\begin{array}{l}\text { The teacher was still confused about the } \\
\text { types of learning media, as evidenced by } \\
\text { including the word interactive video in the } \\
\text { lesson plan. Meanwhile, the learning } \\
\text { media used was interactive multimedia } \\
\text { with a mobile format. }\end{array}$ \\
\hline 5 & $\begin{array}{l}\text { The teacher has tried to plan three } \\
\text { aspects used as an assessment of } \\
\text { student competencies. }\end{array}$ & 5 & $\begin{array}{l}\text { The teacher has not explicitly mentioned } \\
\text { the learning resources on internet use. }\end{array}$ \\
\hline 6 & $\begin{array}{l}\text { The teacher has already made an effort } \\
\text { to make optimal use of the tests or }\end{array}$ & 6 & $\begin{array}{l}\text { Teachers were still not precise in } \\
\text { distinguishing between media and learning }\end{array}$ \\
\hline
\end{tabular}


http://jurnal.uns.ac.id/Teknodika

evaluations in the learning media used. tools.

7 The teacher was not clear and specific about the assessment that students would carry out in learning.

8 The teacher did not explain the function of the assessment link in the lesson plan.

This condition was proven from the document notes obtained. Based on the lesson plan document analysis submitted by the teacher through the network (online), the researcher provided notes on learning objectives, learning syntax, learning resources, learning media, learning assessments, and learning outcomes. On learning objectives, the researcher found that the formulation of learning objectives determined by the teaching teacher was not appropriate. The following is a lesson plan document from the statement of learning objectives.

"Learning Objectives: Students can understand fractions, sample space, and events, and can determine the probability and frequency of expectations of an event."

Based on the learning objectives statement, the output obtained from learning by applying this discovery learning model was not suitable. The target of learning output was in the form of understanding competence. Meanwhile, the purpose of applying the discovery learning model was for students to gain new knowledge of the learning problems they needed through direct learning experiences. According to Edgar Dale's cone of experience, the learning objectives that should be the target (output) to be achieved are that at least students can analyze the knowledge they gain through the direct learning experience. This direct experience could be obtained by utilizing Mobile Education with the title "Probability for an Event", in which there were experiments, sample rooms, and events. Of course, this competency was still lacking because it did not contain elements of affective and student skills. For this reason, in stating learning objectives, the three elements of competence should also be included: affective, cognitive, and psychomotor.

To formulate good learning objectives, Uno (2008) presented the ABCD (Audience, Behavior, Condition, Degree) formulation format. The audience is an actor who is the target of learning. Behavior is behavior that can be observed as a result of learning. Conditions are conditions that must be met for the expected behavior to be fulfilled. Meanwhile, the degree is the level or limits that the target must meet in obtaining learning outcomes. Of course, the formula does not have to be in the A-B-C-D sequence. Based on the ABCD formulation, the learning objectives that the teaching teacher should state are as follows.

"By using the Mobile Education entitled "Probability for an Event", students can carefully analyze and summarize the opportunities and frequency of expectations of an event."

By using the Mobile Education entitled "Probability for an Event" (C), students (A) can carefully (D) analyze and summarize the probability and frequency of expectations of an event (B).

Based on the formulation of the learning objectives, it appears that the competencies targeted at students in learning should be accurate (affective), able to analyze (cognitive), and able to summarize (skills/psychomotor). Besides, the direct experience that students got was through the use of M-Edukasi entitled Probability for an Event. This condition was then cross-checked during the interview. In the syntax section of the lesson plan, some notes were obtained. The first was about the completeness and 
detail of the learning steps. The second was about redundant learning steps. The third was regarding the mention of learning activities. The last one was in terms of naming learning media.

The discovery learning model syntax was contained fully in the lesson plan document made by the teacher but was not detailed. It was not explained in detail what learning activities were carried out at each step of the learning syntax. Besides, the use of M-Edukasi was not explained in which step. After the interview was conducted, the teachers did not specify the syntax because they assumed that the lesson plans were only used for themselves, not for other teachers. In the teacher's lesson plan document, there was a redundant activity recorded. The teaching teacher outlined two similar steps in the lesson plan document: apperception and stimulation. Apperception was given to stimulate students to the topics to be studied. Meanwhile, giving stimulation to students was also carried out in core activities. From this condition, the researcher assumed that the teacher was still inaccurate in preparing the lesson plans for this discovery learning model implementation, including in the closing activities. The teacher only wrote down the assessment points that would be given to students. After conducting interviews, information was obtained that the principal had carried out supervision. However, the direction given to teaching teachers was not optimal. Finally, it had an impact on the quality of lesson preparation which was not optimal either.

Regarding the naming of the media, the researcher also found that there were weaknesses in media knowledge among the teachers. In the main activity, the document was written with an interactive M-Edukasi video. In fact, what was being used was Mobile Education. It was also accidentally discovered by the researcher when conducting interviews. Noting this condition, the researcher noted that the teaching teacher was still generalizing the existing learning media.

In the learning resources and learning media sections, it was found that the teacher listed $\mathrm{M}$ Edukasi with the link http://m-edukasi.kemdikbud.go.id and the internet as a learning resource. Meanwhile, the learning media included were Microsoft Teams - Office 365 and Mobile Education entitled Probability for an Event with the link http://m-edukasi.kemdikbud.go.id/medukasi. Noting this document, the researcher gave several notes. First, the internet is a source of learning that is still common. It is not quite right because many learning resources can be used from the internet. It would be better if the learning resources were mentioned more specifically. Second, the teacher listed Microsoft Teams - Office 365 as a learning medium. At first glance, it is correct, but it actually does not quite fit. The researcher categorized Microsoft Teams - Office 365 as a tool, not a learning media.

Referring to these conditions, the researcher concluded that the teacher was still less aware or focused on the learning resources used. Besides, it was noted that the teacher was still not able to differentiate between tools and learning media. Assessment of learning is one part that also needs to be prepared before carrying out learning. Assessment is an integral part that teachers also need to do (Permendikbud (Regulation of the Minister of Education and Culture) No. 23/2016). Besides, the assessment covers all aspects of competence using various appropriate assessment techniques to monitor and assess the development of students' abilities (comprehensive and continuous). In other words, the assessment given must contain all competency aspects that students or learners must master, including cognitive, affective, and psychomotor.

Based on the documents collected, the researcher in this assessment section noted several things that required attention. According to Permendikbud No. 23 of 2013, the assessment aspect includes three things, covering cognitive, affective, and psychomotor aspects. However, the assessment statement did not clearly measure student competence. In the cognitive assessment, the teacher only stated that the assessment was in the form of an evaluation/written test in distance learning (PJJ). The affective assessment was conducted by observing the presence and activeness of students in PJJ after being confirmed during the interview. Meanwhile, psychomotor assessments were 
stated by assignments in PJJ. In other words, even though the assessment included three aspects, the assessment statement targeted at students was not clear and specific. This evidence was crosschecked during the interview. The teachers have indeed not prepared a comprehensive assessment because they thought that in M-Edukasi, the students were equipped with tests.

Paying attention to these data, it could be concluded that the teaching teacher has already had good intentions and efforts in preparing discovery learning models by utilizing Mobile Education found on the M-Edukasi website. This commitment and effort deserved to be appreciated. The weaknesses found could be used as material to improve teachers' quality and the principal's role as the learning supervisor. With the improvement in teachers' quality and the role of school principals, it is hoped that the learning preparation poured into the lesson plans will be of higher quality as well. Besides, with a quality lesson plan, it is like saying that the boat is in hand; the boat is already in the water; there are already careful preparations; it remains to do a good job. Another benefit if the lesson plan is ready and of good quality is that whomever the implementer is, the learning expected to take place will be according to plan and produce optimal output as well.

From these conclusions, several things need to be corrected in the lessons prepared. Some of these improvements are 1) the formulation of learning objectives should be operational according to the $A B C D$ formula; 2) the formulated learning objectives should refer to three competency aspects that students must master: affective, cognitive, and psychomotor; 3) pouring out the learning steps should be detailed but brief and precise; 4) learning activities should not be divided into the opening, core, and closing, but directly referring to the learning steps from the beginning to the end of the process according to the model applied; 5) knowledge of learning media for teachers should be added because one of the teacher's functions is as a mediator, which facilitates learning with media; 6 ) the assessment should be clearly stated according to the learning objectives.

\section{Transformation Process}

In addition to the input process, the data that was successfully analyzed in the transformation process resulted in strengths and weaknesses, as depicted in Table 2 below.

Table 2. Strengths and Weaknesses of the Transformation Process

\begin{tabular}{clcl}
\hline No. & \multicolumn{1}{c}{ Strengths } & No. & \multicolumn{1}{c}{ Weaknesses } \\
\hline 1 & $\begin{array}{l}\text { The learning carried out has not really } \\
\text { changed the interaction between the }\end{array}$ & $\begin{array}{l}\text { The teacher only delivered the learning } \\
\text { media without instructions on what } \\
\text { activities need to be done to support the } \\
\text { deacher and students because it was } \\
\text { carried out altogether using Microsoft } \\
\text { Teams - Office } 365 \text { with the help of } \\
\text { WhatsApp to share the media used. }\end{array}$ & $\begin{array}{l}\text { liscovery } \\
\text { implementation. }\end{array}$ \\
\hline 2 & $\begin{array}{l}\text { Activities at the beginning of learning could } \\
\text { be carried out properly according to the } \\
\text { lesson plan. }\end{array}$ & $\begin{array}{l}\text { The teacher did not emphasize the use } \\
\text { of M-Edukasi, so that the implementation } \\
\text { of tests or evaluations in the learning } \\
\text { media used was not optimal. }\end{array}$ \\
\hline 3 & $\begin{array}{l}\text { The use of M-Edukasi could be carried out } \\
\text { well thanks to the teacher's guidance. }\end{array}$ & $\begin{array}{l}\text { The assignment did not pay attention to } \\
\text { the topics that should be completed. }\end{array}$ \\
\hline 4 & $\begin{array}{l}\text { Learning was complemented by giving } \\
\text { assignments to make conclusions. }\end{array}$
\end{tabular}

Based on this data presentation, it could be analyzed that the principal has successfully carried out his role as manager by providing opportunities for teachers and students to take advantage of 
available digital technologies, such as Microsoft Teams - Office 365 and M-Edukasi. Teachers and students could make good use of existing technology. With these tools, direct interactions between teachers and students hindered during the COCID-19 pandemic were disguised. Not only that, but the teacher could guide students to take advantage of M-Edukasi in the learning carried out. In its implementation, the teacher has made efforts according to the lessons compiled. It could also be seen from the observation results and confirmed during the interview.

The model implementation began with providing a stimulus to students in the form of several pictures taken free from Google to lead students to focus on the topic to be studied. The core activity was carried out entirely by utilizing M-Edukasi without specifying the steps to be followed and what activities students needed to do. Based on interviews with teachers, it was found that data collection activities to data verification were carried out using mobile learning with the title "Probability for an Event" on the M-Edukasi website. In fact, the use of mobile education can be done at one of the steps in the applied discovery learning model. From these data, it could be concluded that the learning processes were less structured.

Regarding the use of media from M-Edukasi, it was conveyed by the teacher that the material contained in the media was complete. However, technically, the use of this media encountered several obstacles. Some students had problems opening the media used even though it had been given in the form of downloads sent via the WA group. The loading time required to open the media was quite long. Besides, this media requires an SWF reader. The use of M-Edukasi with the title "Probability for an Event" was essentially beneficial for teachers in conveying the topic "Opportunities and Expectations of an Event Frequency", although technically, students still had problems with loading times and the required supporting software. The teacher, in this case, has carried out his role as a guide well. However, as an educator, the teacher should explore more techniques for applying methods to the applied learning model. Based on the conditions obtained, the discovery learning model implementation weaknesses by utilizing Mobile Education in M-Edukasi were due to the teacher's lack of clear and detailed instructions. The teacher should convey what activities students need to do while using the learning media, likewise, for the assignments given. This weakness was due to the lack of detail in teacher preparation in the lesson plan and the incomplete learning media with instructions for use. This condition ultimately impacted the resulting output.

\section{Output Process}

Student learning outcomes which were the outputs of learning, were less than optimal. Even though it had been valued from the three competency aspects, the cognitive aspect was clearly detected. The affective aspects that were said to be obtained from the presence and activeness of students actually did not represent the purpose of implementing the discovery learning model itself, namely, gaining new knowledge from the learning experience, they go through directly. Referring to this implementation purpose, every step of the activity should be meaningful to students if given clear activity instructions and results. Affective aspects that could arise from students were activeness, thoroughness, and discipline in participating in learning and collecting assignments. Attendance in the learning classroom, even though it was virtual, was an inevitable obligation on students. Meanwhile, the psychomotor aspects assigned to students also did not fully cover the subjects studied. This condition was due to the teacher's lack of detail in expressing student assessments in the lesson plan. 
From the documented assessment data, the researcher noted several things. The researcher found that the assessment carried out on students was only on the cognitive assessment. Of the 67 students who participated in this learning, 15 students scored below the KKM (Minimum Completion Criteria) set by the school, 70 . In other words, there were $22.39 \%$ of students obtained cognitive results below the KKM. Other assessments did not show any results, even though from the observation results the researcher obtained, the teacher had given assignments for students to make conclusions. However, students' summaries or conclusions were still in the form of a definition of the probability of the event, not yet on how to determine the probability and frequency of expectations of the event. In other words, the learning objectives seemed to have not been completed by students.

From the three processes obtained: input, transformation, and output, it could be concluded that the three processes were interrelated and influenced; if it were good in one previous process, it would have a good impact on the next process, and vice versa. This evaluation's results were then reviewed to provide feedback for further improvements.

\section{Feedback Process}

Some feedbacks from the evaluation of the discovery learning model implementation using Mobile Education on the M-Edukasi website are as follows. In the transformation process, the weaknesses that occurred during the learning implementation were actually caused by a lack of clear and detailed instructions from the teacher to the students. It happened because the teacher's preparation as outlined in the lesson plan was less detailed. Besides, the learning media used were also not equipped with instructions for use, making it a little difficult for the teacher because there were no guidelines. Furthermore, in the resulting output, there was a lack of optimal learning outcomes obtained. This condition was also caused by the lack of detail in the teacher's planning assessment in the lesson plan that was in accordance with the discovery learning model applied.

In essence, the weaknesses in the discovery learning model implementation by utilizing Mobile Education on M-Edukasi were influenced by the lack of quality of lesson plans and the absence of instructions for utilization in the learning media used. For this reason, in the next implementation, it is hoped that there will be an increase in the quality of the lessons used and the availability of instructions for using media as a guide for users. As for briefly, the process and results are displayed in the following figure.

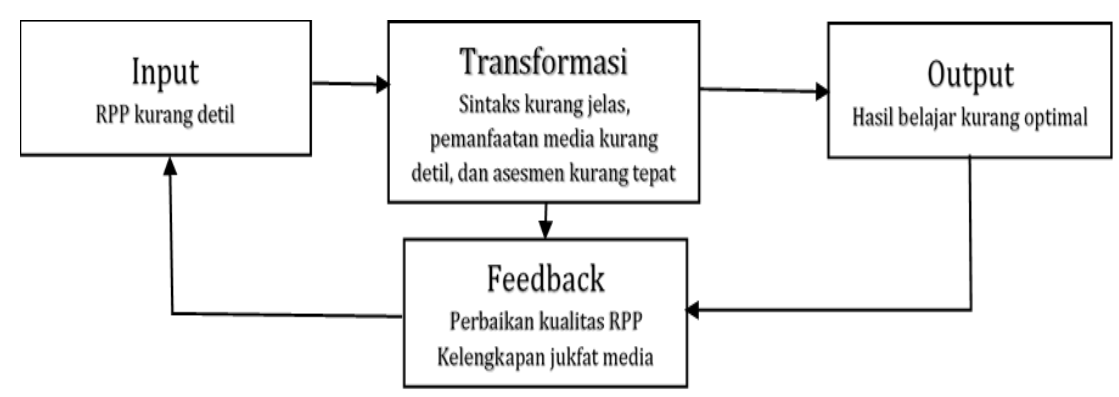

Figure 4. Process and Evaluation Results of the Discovery Learning Model Implementation with MEdukasi. 


\section{CONCLUSION AND SUGGESTION}

This study evaluated the discovery learning model implementation by utilizing M-Edukasi, a content website developed by the Center for Multimedia Education and Culture Development (BPMPK). The research targets were teachers and school principals of SMA Negeri 1 Wonogiri, with the research scope on Mathematics learning using Mobile Education. From the implementation evaluation carried out, the following results were obtained. The three learning processes from preparation, implementation, and learning outcomes were interrelated and influenced. If it were good in one previous process, it would have a good impact on the next process, and vice versa. The weaknesses found in the learning implementation were influenced by the lesson plan's weakness that was less detailed and clear in the document. Besides, it was also revealed that the use of Mobile Education on M-Edukasi was still less than optimal. It was because there were no usage instructions that complemented the learning media used. These weaknesses ultimately impacted student learning output that was less than optimal. In other words, these weaknesses originated from the weakness of the lesson plans compiled by the teacher and the incomplete learning media used with instructions for use. It is what then becomes feedback for improvements in the next learning model implementation.

Paying attention to the results obtained from research on the discovery learning model implementation by utilizing M-Edukasi, the principal and teachers are advised to continue to improve their abilities in applying learning models by utilizing ICT. In this case, the qualified principal and teachers will produce students with complete and quality competencies. Therefore, teachers are advised to compile quality lesson plans so that the implementation and assessment of learning will be optimal. The principal should continue to supervise the learning applied by the teachers. In connection with the use of M-Edukasi, it is recommended that BPMPK complete each learning media developed with instructions for use. It is to make it easier for users to implement its use in learning. Moreover, it is recommended to research other learning models. By evaluating the model implementation, it is hoped that the quality of the learning applied to start from the preparation, implementation, and learning outcomes obtained will be better.

\section{REFERENCES}

Afandi, M., Chamalah E., dan Wardani, O.P. (2013). Model dan Metode Pembelajaran di Sekolah. Semarang: UNISSULA PRESS.

Arifin, Zainal. (2013). Evaluasi Pembelajaran: Prinsip, Teknik, Prosedur. Bandung: PT. Remaja Rosdakarya

Asrul, Ananda R., \& Rosnita. (2014). Evaluasi Pembelajaran. Bandung: Citapustaka Media

Brown, Emily. (2006). Discovery Learning in the Classroom. Diunduh tanggal 17 Desember 2020, (PDF) Discovery Learning in the Classroom (researchgate.net)

Kemendikbud. (2016). Permendikbud no. 23 tahun 2016: Standar Penilaian Pendidikan. Jakarta: Kemdikbud. Diunduh tanggal 18 Agustus 2020

Manikowati. (2017). The Effectiveness of Task-Based Learning Using Tutorial and Game Interactive Multimedia Instructions in Learning Recount Text Writing to Students with Visual and Auditory Learning Styles. Semarang: Unnes, thesis.

Miles, M.B. \& Hubberman, M. (1992). Analisis data kualitatif Terj. Tjejep Rohidi. Jakarta : UI Press

Moleong, L.J., (2008). Metode Penelitian Kualitatif. Edisi Revisi. Bandung: PT. Remaja Rosdakarya

Nikmah, Apriantika K., (2017). Kerucut Pengalaman Edgar Dale. Diunduh tanggal 26 November 2020, https://civitas.uns.ac.id 
Novita, F., Irawati, S., dan Jumiarni, D., (2017). Peningkatan Aktivitas dan Hasil Belajar melalui Model Discovery Learning dengan Pendekatan Saintifik. Diklabio: Jurnal Pendidikan dan Pembelajaran Biologi 2(2)

Nurdin Usman. (2002). Konteks Implementasi Berbasis Kurikulum, Jakarta: PT. Raja Grafindo Persada.

Nurdiyansyah \& Fahyuni, E.F., (2016). Inovasi Model Pembelajaran Sesuai Kurikulum 2013. Sidoarjo: Nizamia Learning Center

Purwaningrum, J.P., (2016). Kemampuan Berpikir Kreatif Matematis Melalui Problem Based Learning "What's Another Way" dan Discovery Learning. Teknodika, 16 (01) DOI: https://doi.org/10.20961/teknodika.v14i1.34699

Rahmayani, Aprillia. (2019). Pengaruh Model Pembelajaran Discovery Learning dengan Menggunakan Media Video terhadap Hasil Belajar Siswa. Jurnal Pendidikan, 04 (01). DOI: 10.26740/jp.v4n1.p59-62

Riyaningsih, E., Maryono, \& Harini. (2018). Pembentukan Karakter Bagi Peserta Didik Sekolah Menengah Atas Dalam Pembelajaran Seni Tari Melalui Model Discovery Learning. Teknodika. 16 (02) DOI https://doi.org/10.20961/teknodika.v16i2.34778

Uno, Hamzah. (2008). Perencanaan Pembelajaran. Jakarta: Bumi Aksara.

Tachjan. (2006). Implementasi Kebijakan Publik. Yogyakarta: Pustaka Pelajar. 